\begin{tabular}{l} 
DUTRNA, RIS'T \\
(Rekayasa Sistem dan Teknologi Informasi) \\
Vol.3 No.2 (2019) $124-130 \quad$ ISSN Media Elektronik: $2580-0760$ \\
\hline
\end{tabular}

\title{
Implementasi Game Based Learning pada Pembelajaran Bahasa Inggris
}

\author{
Nindian Puspa Dewi ${ }^{1}$, Indah Listiowarni ${ }^{2}$ \\ ${ }^{1,2}$ Teknik Informatika, Teknik, Universitas Madura \\ ${ }^{1}$ nindianpd@unira.ac.id, ${ }^{2}$ indah@unira.ac.id
}

\begin{abstract}
Games are media that can be used in the learning process to stimulate students in teaching and learning activities in the classroom. The game used is a game that has been adapted to the needs of learning in the classroom called game based learning or educational games. English subjects are difficult to learn by elementary students at SDN Bujur Barat II, so the use of learning media is needed to attract students' interest in learning the subject. In this study, an educational game was made based on the SD English curriculum consisting of writing, reading, listening, and speaking, which was built using the Ionic programming language and the PHP Framework.
\end{abstract}

Keywords: game, education, learning, mobile

\begin{abstract}
Abstrak
Game merupakan media yang bisa digunakan dalam proses belajar untuk menstimulasi siswa dalam kegiatan belajarmengajar di dalam kelas. Game yang dimaksud merupakan game yang sudah disesuaikan dengan kebutuhan pembelajaran di dalam kelas yang disebut game based learnimg atau game edukasi. Mata pelajaran bahasa inggris merupakan mata pelajaran yang dirasa sulit untuk dipelajari oleh siswa tingkat dasar SDN Bujur Barat II, sehingga penggunaan media pembelajaran sangat dibutuhkan untuk menarik minat siswa dalam mempelajari subjek tersebut. Pada penelitian ini, digunakan game edukasi yang dibuat berdasarkan kurikulum Bahasa Inggris SD yang terdiri dari menulis, membaca, mendengarkan, dan berbicara, yang dibangun dengan menggunakan bahasa pemograman Ionic dan Framework PHP.
\end{abstract}

Kata kunci: game, edukasi, learning, mobile

(C) 2019 Jurnal RESTI

\section{Pendahuluan}

Pada abad ini, penggunaan Teknologi Informasi dan komunikasi meningkat semakin tajam dan mulai merambah pada semua bidang, tidak terkecuali penggunaan nya pada bidang pendidikan [1]. Dalam dunia pendidikan, TIK dibutuhkan untuk membuat proses belajar-mengajar antar guru dan murid menjadi lebih informative, kreatif dan inovatif karena proses belajar-mengajar di dalam kelas menentukan tingkat keberhasilan siswa dan guru. Implementasi TIK dalam dunia pendidikan adalah dengan menerapkan pembelajaran online pada game edukasi berbasis kurikulum atau sebuah game yang telah disesuaikan dengan porses pembelajaran.

Game based learning adalah sebuah permainan (game) yang sengaja dibuat untuk keperluan edukasi sebagai penunjang media pembelajaran, karena dianggap lebih menarik dibandingkan proses belajar mengajar yan konvensional. Game based learning terbukti dapat meningkatkan prestasi siswa dan menunjang proses pendidikan [2][3]. Hal ini berhubungan dengan design yang digunakan pada game edukasi, yang terdiri dari animasi, pemilihan warna yang sesuai dan ilustrasi (objek) yang menarik pada setiap tahap pembelajaran ataupun setiap topik pada pembelajaran yang kemudian diterapkan pada game edukasi (education game) dengan tujuan untuk merangsang siswa Sekolah Dasar untuk mencintai mata pelajaran yang sulit dipahami, yaitu pada penelitian ini adalah mata pelajaran Bahasa Inggris, dimana mata pelajaran tersebut merupakan bahasa universal yang harus mulai dipahami sejak pendidikan dasar. Siswa yang sedang mengenyam bangku pendidikan dasar, cenderung masih lebih menyukai permainan daripada proses belajar yang monoton dan teoritis di dalam kelas. Sehingga dibutuhkan media pembelajaran yang tepat untuk menstimulasi kemampuan belajar siswa. 
Pembuatan game edukasi berbasis mobile disesuaikan pengumpulan data/konsultasi antar customer dan dengan jenjang dan kurikulum tempat penerapan game pengembang, dilanjutkan dengan analisis siste, edukasi (education game) tersebut. Pada penelitian ini, pengkodean, dan pemeliharaan (maintenance). Pada studi kasus penerapan game edukasi dilakukan pada metode prototype tahapan maintenance bukan sebuah sekolah di Kabupaten Pamekasan, yaitu Sekolah merupakan tahapan akhir dari proses pembangunan Dasar Negeri (SDN) Bujur Barat II, dan diterapkan perangkat lunak, yaitu terjadi siklus perputaran kembali pada Mata Pelajaran Bahasa Inggris yang disesuaikan ke tahapan awal yaitu pengumpulan data yang terdiri dengan kurikulum mata pelajaran. Diantaranya terdiri dari konsultasi dan wawancara jika dibutuhkan dari teori-teori seperti membaca (reading), menulis pengembangan versi atau terjadi error pada perangkat kalimat (writing), memilih kata yang tepat untuk lunak yang sedang dikembangkan. [8]

melengkapi kalimat kosong (tata bahasa), dan mencocokkan gambar dengan bahasa inggris yang benar. Kemampuan siswa di kelas dalam mempelajari Tahap awal yang dilakukan adalah pengumpulan data, mata pelajaran bahasa inggris menggunakan game Tahapan ini dilakukan dengan tujuan untuk edukasi akan diukur dan kemudian ditampilkan dalam memperoleh data yang sesuai dengan keperluan papan score, untuk menstimulasi daya saing siswa perancangan game edukasi di SDN Bujur Barat II. untuk terus belajar menjadi yang terbaik.

Beberapa penelitian penerapan game mobile pada proses belajar-mengajar di sekolah, juga pernah dilakukan dalam penelitian lain, yaitu pada pembelajaran anak usia dini untuk mengenal bentuk dan warna benda[4], meningkatkan daya ingat anak usia dini pada topik matematika dasar, mengelompokkan nama-gambar sayuran, binatang dan buah-buahan menggunakan metode waterfall [5], dan game edukasi yang dibuat untuk anak usia dini berusia 3-6 tahun yang berisi tentang materi pelajaran mengenal binatang, mewarnai, corat-coret, menyanyi serta alfabet, yang sengaja dibuat untuk anak berusia 36 tahun karena dipercaya merupakan umur, dimana anak-anak memasuki umur keemasan [6].

\section{Metode Penelitian}

Sehingga dilakukan 2 macam pendekatan metode pengumpulan data yaitu Pengamatan (observasi) secara langsung, yaitu pengamatan yang dilakukan langsug di tempat penelitian untuk mengetahui penerapan kurikulum mata pelajaran bahasa inggris, dan wawancara (interview) dilakukan dengan mengajukan pertanyaan terkait penelitian kepada guru atau wakil kepala sekolah kurikulum, untuk mengetahui proses belajar mengajar dan penerapan kurikulum di SDN Bujur Barat II.

\subsection{Analisis Sistem}

Analisis sistem merupakan tahapan yang dilakukan setelah tahapan pengumpulan data selesai dilakukan. Analisis sistem merupakan tahapan rancangan sebuah perangkat lunak, mulai dari sketsa, penggambaran, perencanaan dan skenario yang dibutuhkan[9]. Pada penelitian ini tahapan analisis sistem dilakukan dengan Metode Penelitian merupakan sebuah gambaran perancangan prototype game mobile berbasis tahapan yang dilakukan dalam melakukan sebuah kurikulum di SDN Bujur Barat II, yang terdiri dari use penelitian atau melakukan sebuah perancangan case diagram, activity diagram dan perancangan perangkat lunak [7]. Pada penelitian ini, metode kebutuhan tabel yang akan ditampilkan dalam bentuk penelitian yang digunakan adalah metode prototype Conceptual data model pada gambar 9. (prototype method).

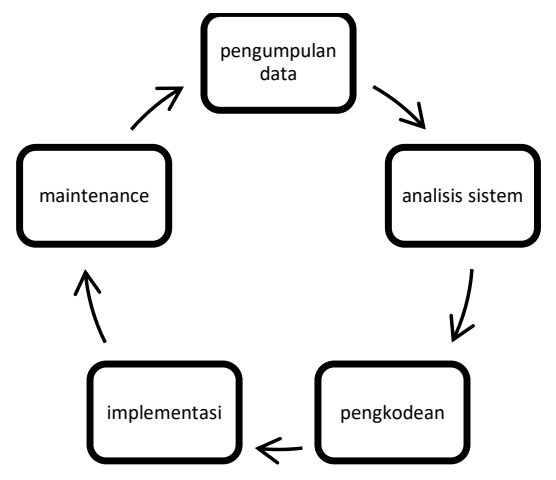

Gambar 1. prototype
Use case diagram pada gambar 2 dibuat berdasarkan sudut pandang pengguna game mobile berbasis kurikulum, yaitu pada penelitian ini merupakan siswa dan guru SDN Bujur Barat II.

Activity Diagram menggambarkan berbagai aliran aktivitas dalam sistem yang dirancang, bagaimana masing-masing fungsionalitas bekerja, dan bagaimana suatu fungsionalitas berakhir [10]. Activity Diagram memodelkan event-event yang terjadi pada use case. Diagram ini sangat mirip dengan flowchart karena memodelkan workflow dari satu aktivitas ke aktivitas lainnya atau dari aktivitas ke status

Seperti yang terlihat pada gambar 1, tahapan pada prototype method yang akan diterapkan pada penelitian ini terdiri dari 6 tahapan yang saling berkaitan dan terjadi memiliki siklus berputar, dimulai dari langkah 

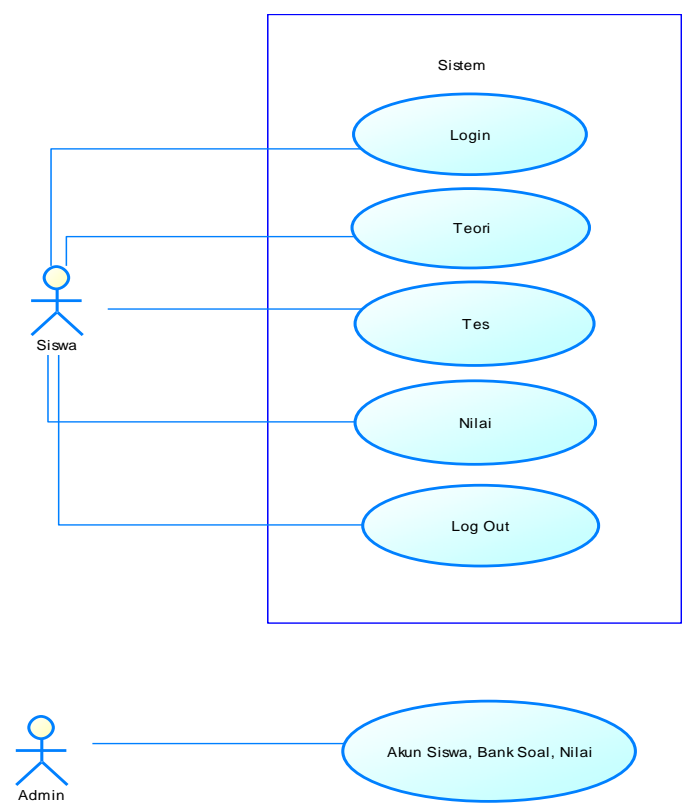

Gambar 2. Use Case Diagram

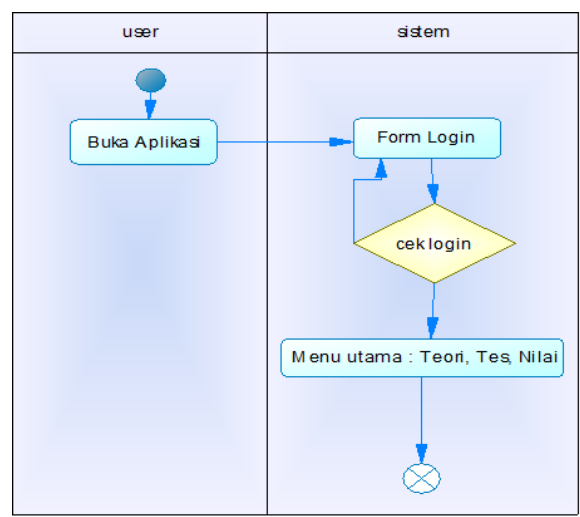

Gambar 3. Activity Diagram Menu Mulai Siswa

Gambar 3 menjelaskan alur User/ Siswa pada saat melakukan login atau masuk ke game, sebelumnya game mobile berbasis kurikulum akan melakukan pengecekan username dan password yang dimasukkan oleh siswa dan sistem akan mengarahan ke menu utama.

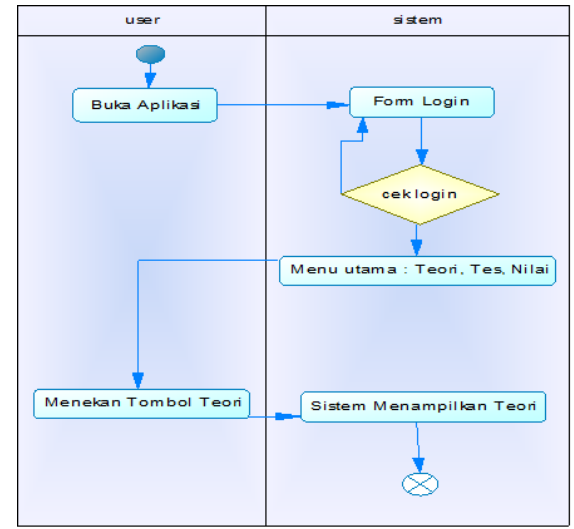

Gambar 4 Activity Diagram Memilih Menu Teori
Pada Gambar 4 merupakan activity diagram yang menggambarkan saat siswa memilih menu teori, yaitu sebuah menu dimana siswa dapat belajar sesuai dengan kurikulum dan buku pelajaran bahasa inggris yang telah diterapkan di sekolah.

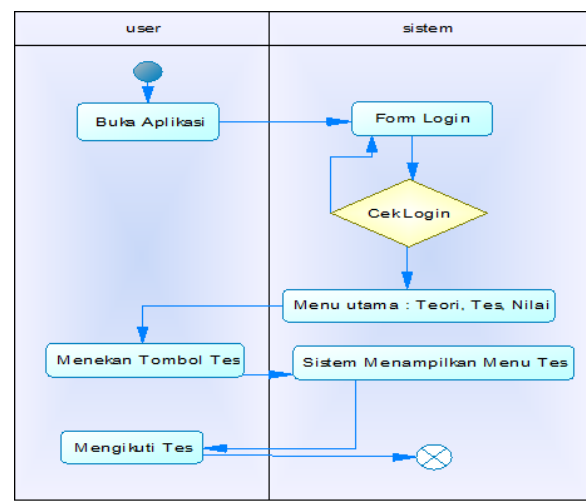

Gambar 5 Activity Diagram Memilih menu tes

Gambar 5 merupakan activity diagram menggambarkan jika user siswa memilih menu tes, yaitu sebuah menu merupakan dimana siswa dapat melakukan uji coba atau tes berdasarkan teori yang dipelajari pada menu teori sebelumnya.

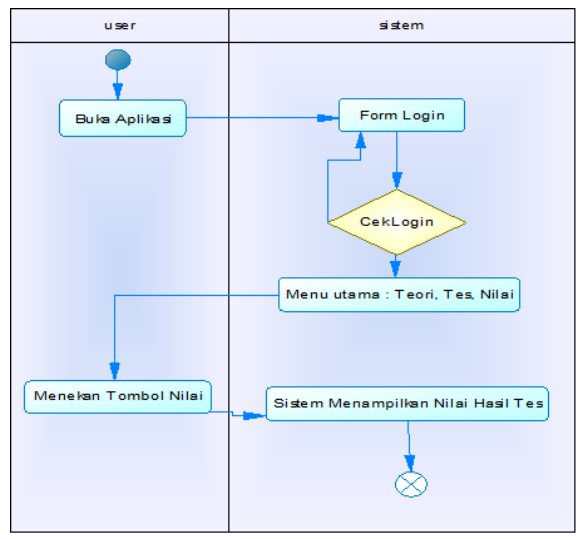

Gambar 6 Activity Diagram Memilih Menu Nilai

Gambar 6 meruapakan skenario user yang digambarkan pada activity diagram, menjelaskan jika user memilih menu nilai yang di dalamnya terdapat nilai yang diperoleh siswa setelah melakukan tes.

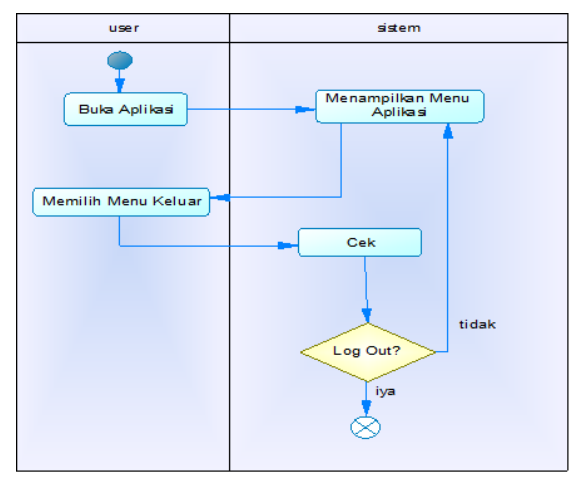

Gambar 7 Activity Diagram Memilih Menu Keluar 
Gambar 7 menjelaskan user memilih menu keluar yang 2.3. Pengkodean merupakan tombol untuk keluar dari aplikasi tersebut.

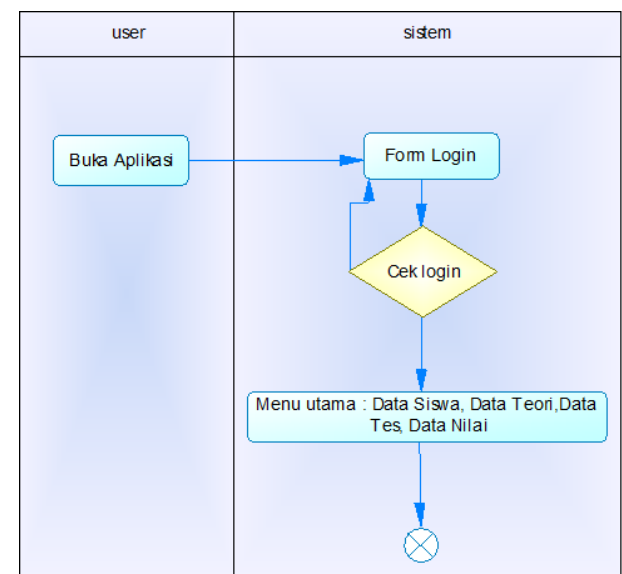

Gambar 8 Activity Diagram Memilih Menu Mulai guru
Selain siswa sebagai user, pada penelitian ini juga terdapat user guru yang bertugas untuk mengontrol nilai siswa, melakukan olah (menambah, mengubah dan menghapus) data siswa, teori mata pelajaran bahasa kaitannya dengan kesesuaian kurikulum yang inggris dan data tes. Pada Gambar 8 menjelaskan user digunakan pada SDN Bujur Barat II, Mata Pelajaran, guru melakukan login atau masuk ke sistem, asistem Minat siswa dalam menggunakan game edukasi, user akan melakukan pengecekan username dan password friendly terhadap semua user, dan peningkatan hasil yang dimasukkan oleh guru dan aplikasi akan belajar siswa terhadap mata pelajaran yang dijadikan mengarahkan ke halaman menu utama.

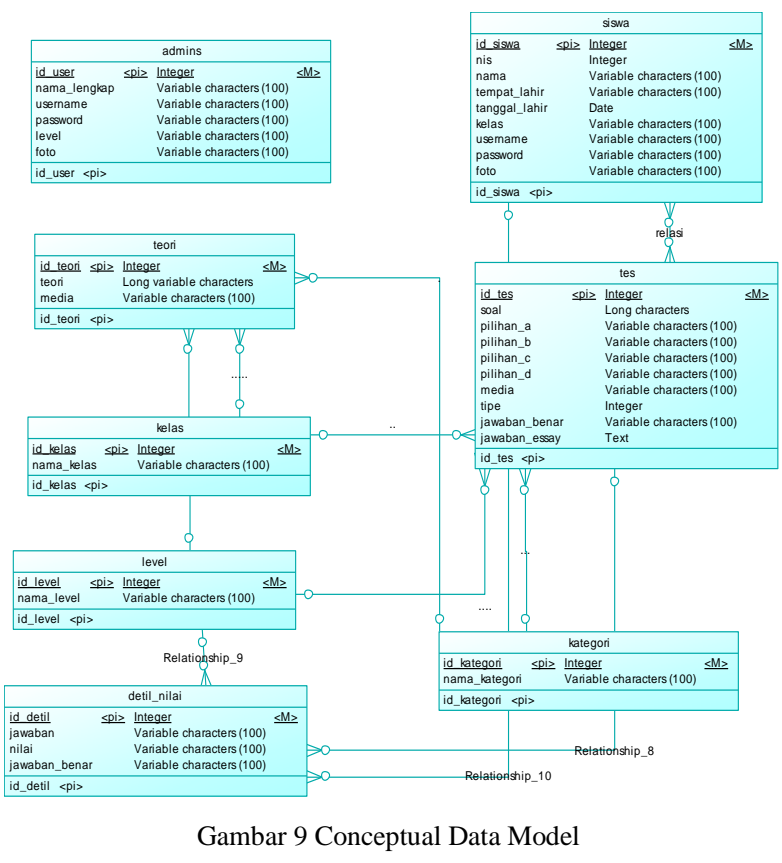

Gambar 9 menjelaskan tentang hubungan tabel yang (wembaca (reading), menulis (witing), mendengar dibutuhkan dan digunakan di dalam sistem yang juga dibuat dengan mengutamakan tampilan yang ditampilkan dalam bentuk conceptual data model. Pada menarik dan mudah digunakan oleh siswa sekolah penelitian ini tabel yang dibutuhkan berjumlah 8 tabel, dasar.

terdiri dari tabel admins, tabel teori, tabel tes, tabel Selanjutnya sesuai dengan yang telah dijelaskan pada kelas, tabel kelas, tabel detil nilai, tabel kategori dan gambar 1, tentang tahapan metode penelitian yang tabel siswa yang saling berhubungan.
Setelah selesai melakukan tahapan analisis dan ancangan sistem, tahapan selanjutnya yang harus pengkodean (coding),pada tahapan ini dilakukan perakitan setiap komponen game menjadi satu kesatuan gane yah, dengan menggunakan bahasa ditampilkan pada user, dan bahasa pemograman PHP framework sebagai tampilan admin (server).

\subsection{Implementasi}

Tahap impelementasi merupakan tahapan peluncuran perangkat lunak yang telah dirancang dan dibangun dan ujicoba game edukasi, apakah game edukasi yang telah selesai dibangun sesuai dengan keinginan dan kenyataan pada lapangan (studi kasus) yaitu SDN Bujur Barat II. objek penelitian, yaitu Bahasa Inggris

\subsection{Pemeliharaan}

Tahapan maintenance merupakan Tahapan setelah tahap implementasi dilakukan seperti yang ditunjukkan paada gambar 1. Game yang sudah jadi dan digunakan, akan dilakukan maintenance/pemeliharaan jika dibutuhkan, misalnya memperbaiki kerusakan/error sampai pembaruan versi.

Seperti yang telah dijelaskan sebelumnya, tahap pemeliharaan bukan tahapan akhir, karena tahapan pemeliharaan bisa kembali pada tahapan pengumpulan data jika dibutuhkan, sehingga alur proses pada metode prototype berbentuk seperti kumpalan (circle)

\section{Hasil dan Pembahasan}

Tujuan utama pembuatan game edukasi ini adalah untuk menarik minat siswa pada pembelajaran Bahasa Inggris. Karena itulah game ini dibuat dengan berdasarkan pada kurikulum yang berlaku dengan menerapkan empat kategori utama yaitu kemampuan membaca (reading), menulis (writing), mendengar digunakan, tahapan implementasi merupakan tahapan setelah tahapan pengkodean dilakukan. 
Pada penelitian ini, implementasi sistem terdiri dari 2 Untuk menu data kelas digunakan hanya untuk user yaitu guru dan siswa, dan terdapat 2 tampilan menambah kelas sesuai dengan kebutuhan sekolah implementasi sistem, yaitu implementasi server yang normalnya untuk sekolah dasar dimulai dari kelas menggunakan bahasa pemograman PHP framework satu sampai dengan kelas enam. Menu data level yang dikususkan untuk admin yang bertugas mengolah digunakan untuk menambah level atau tingkatan data teori dan soal yang akan ditampilkan di tampilan permainan yang akan dibuat. Sedangkan untuk menu game (user), dan tampilan game untuk user data kategori adalah data yang berisi kategori dari teori menggunakan bahasa pemograman mobile berbasis dan soal sesuai dengan kurikulum yang terdiri dari android.

listening, reading, writing dan speaking.

\subsection{Implementasi Pada Server}

Pada sisi server, user dapat melakukan manipulasi data master yang meliputi menu data user, data siswa, dan data kelas. Selain itu terdapat menu data level, data kategori, data teori dan data soal.

Menu data user adalah menu yang digunakan untuk melakukan manipulasi data user. User pada menu ini adalah admin yang merupakan user tertinggi yang dapat menambah, menghapus dan mengedit data lainnya. Selain itu user adalah guru yang memiliki level operator yang tidak bisa menghapus, menambah dan mengedit user lainnya. Gambar 10 menunjukkan tampilan menu data user.

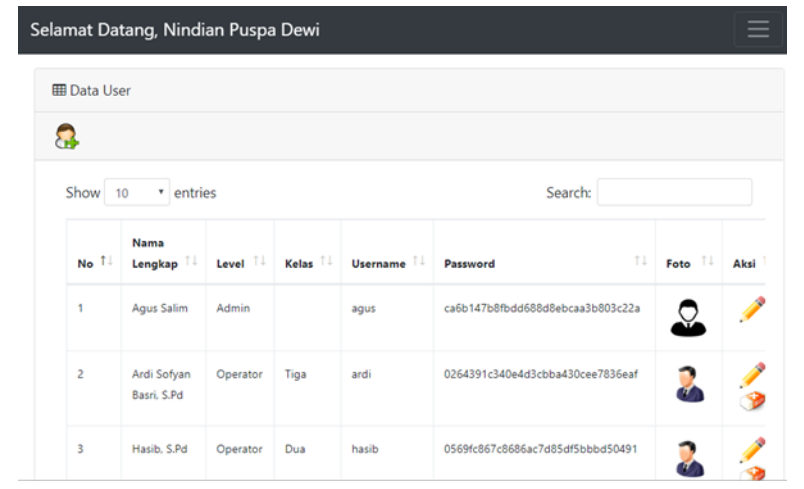

Gambar 10 Tampilan Menu Data User

Menu data siswa adalah menu yang digunakan untuk menambah, menghapus dan mengedit data siswa. Admin atau operator dapat melakukan penambahan data siswa dengan cara menekan tombol Tambah Data. Berikut tampilan menu data siswa dapat dilihat pada gambar 11 berikut.

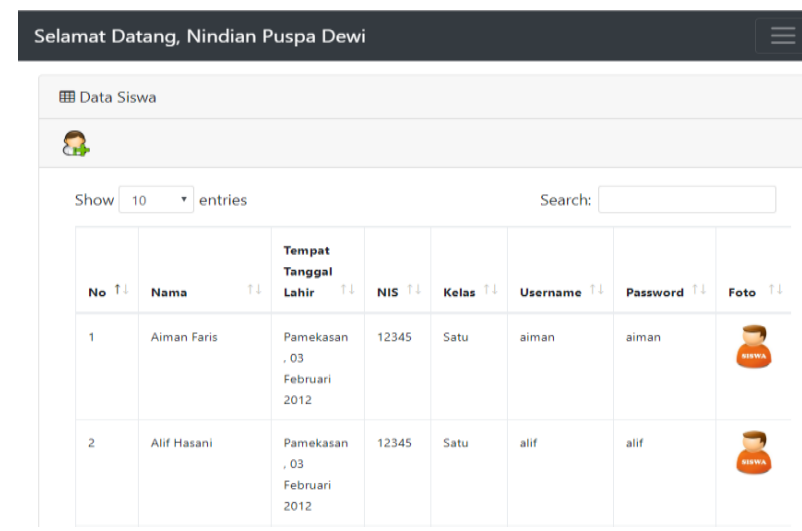

Gambar 11 Tampilan Menu Data Siswa
Teori dibuat pada menu data teori dengan memasukkan kelas, level dan kategori dari teori yang akan dibuat. Teori dapat dibuat mengikuti kurikulum yang ditentukan dengan memilih level dan kategori. tampilan menu data teori dapat dilihat pada gambar 12 berikut ini.

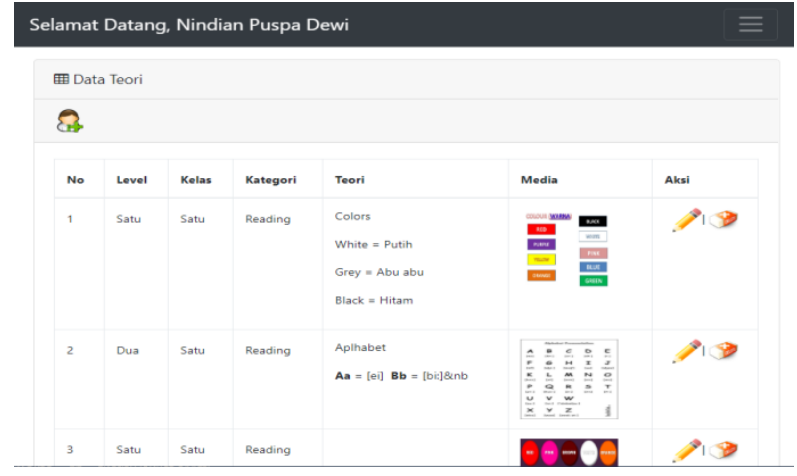

Gambar 12 Tampilan Menu Data Teori

Sama halnya dengan data teori, untuk menambah soal dilakukan dengan memasukkan kelas, level dan kategori dari soal yang akan dibuat. Soal dalam game edukasi ini dapat dibuat dengan model soal uraian maupun soal pilihan ganda. Gambar 13 menunjukkan tampilan menu data tes atau soal.

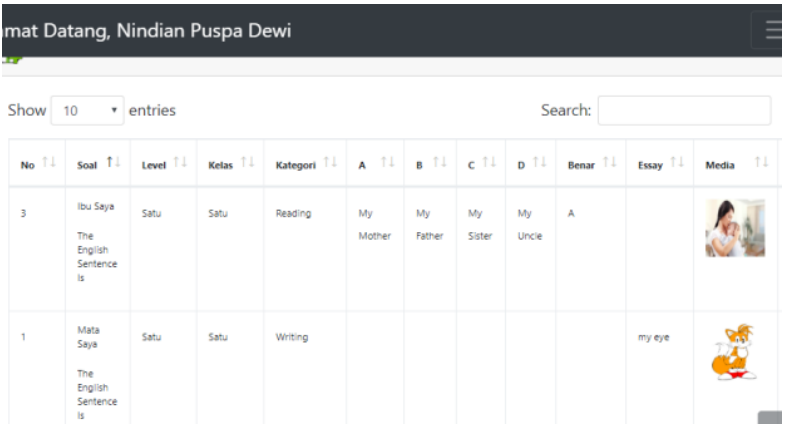

Gambar 13 Tampilan Menu Data Tes

Melalui sisi ini user juga dapat melihat skor yang diperoleh siswa setelah menjawab soal. Skor inilah yang nantinya dapat digunakan sebagai nilai tugas, tambahan atau rujukan nilai akhir siswa. Berikut tampilan menu data nilai dapat dilihat pada gambar 14 .

\subsection{Implementasi Pada Game}

Sisi ini adalah antar muka yang digunakan oleh siswa untuk belajar dan mengerjakan soal/tes secara online baik di rumah maupun di sekolah. Jika sisi server 
berbasis web, untuk sisi ini menggunakan android yang digunakan dalam smartphone. Saat membuka aplikasi siswa akan diminta login dengan memasukkan username dan password yang telah dibuat oleh admin sebelumnya. Gambar 15 menunjukkan tampilan login siswa.

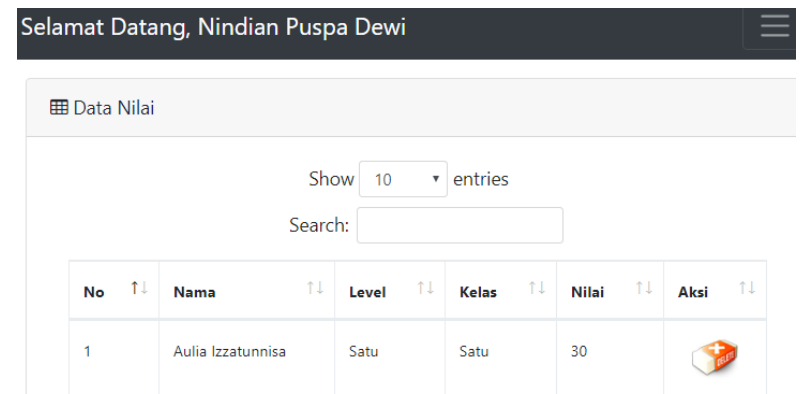

Gambar 14 Tampilan Menu Data Nilai

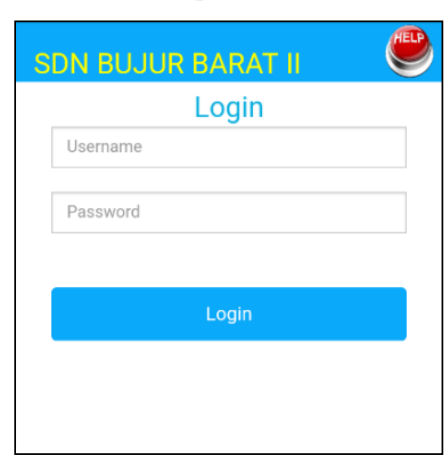

Gambar 15 Tampilan Login Siswa

Setelah berhasil login, akan tampil menu utama. Menu utama terdiri dari teori, test, score, top score dan keluar. Tampilan menu utama dapat dilihat pada gambar 16.

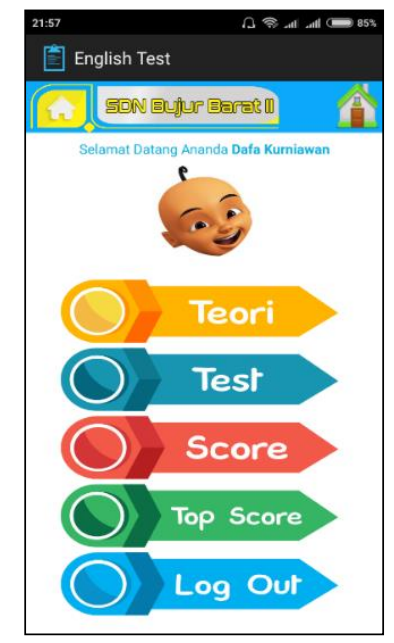

Gambar 16 Tampilan Menu Utama

Menu teori menampilkan teori yang telah dibuat oleh guru sesuai dengan kelas siswa. Teori dapat dipelajari secara bertahap sesuai dengan level dan kategori yang sesuai dengan kurikulum. Berikut tampilan menu teori dapat dilihat pada gambar 17.

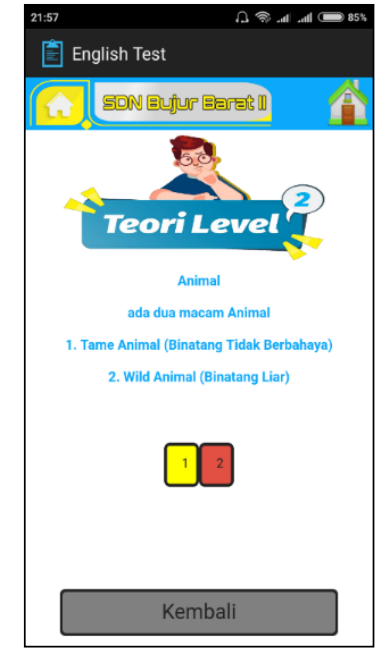

Gambar 17 Contoh Tampilan Teori

Selanjutnya setelah mempelajari teori dalam menu teori, siswa dapat mengerjakan soal tes pada menu test. Soal dapat dikerjakan secara berurutan dari level terendah ke tertinggi. Siswa tidak diijinkan mengerjakan soal jika secara acak. Gambar 18 menunjukkan contoh tampilan menu test. Menu ini akan menampilkan data tes untuk user. Tombol Jawab digunakan untuk menjawab tes. Sedangkan tombol Kembali digunakan untuk kembali ke menu awal.

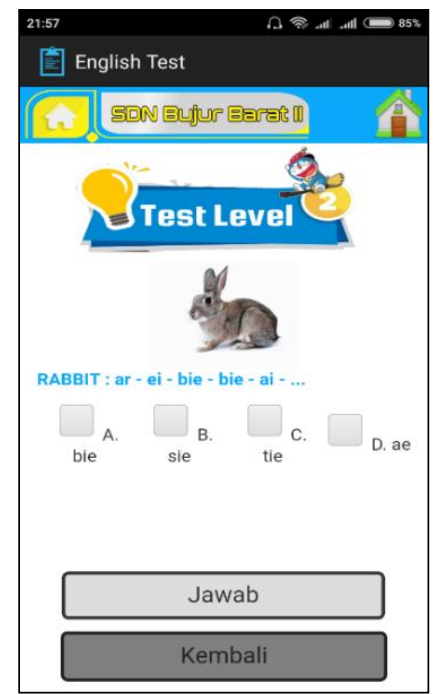

Gambar 18 Contoh Tampilan Menu Test

Siswa dapat melihat nilai hasil test mereka dengan memilih menu Score. Gambar 19 menunjukkan tampilan menu score salah satu siswa dimana score yang ditampilkan adalah score yang diperoleh pada tiap level.

Sebagai pemicu semangat siswa untuk memperoleh nilai terbaik, ditampilkan juga top score atau sepuluh nilai terbaik yang berhasil diperoleh oleh siswa sesuai dengan kelas dan level terakhir yang harus dikerjakan oleh siswa. Berikut contoh tampilan top score dapat dilihat pada gambar 20. 


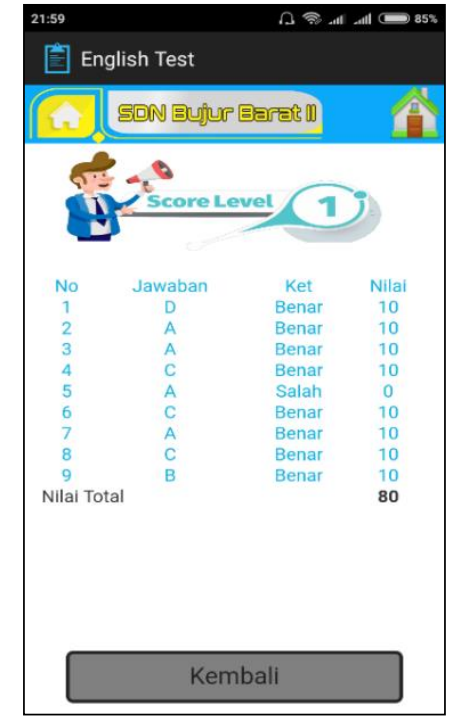

Gambar 19 Contoh Tampilan Menu Test

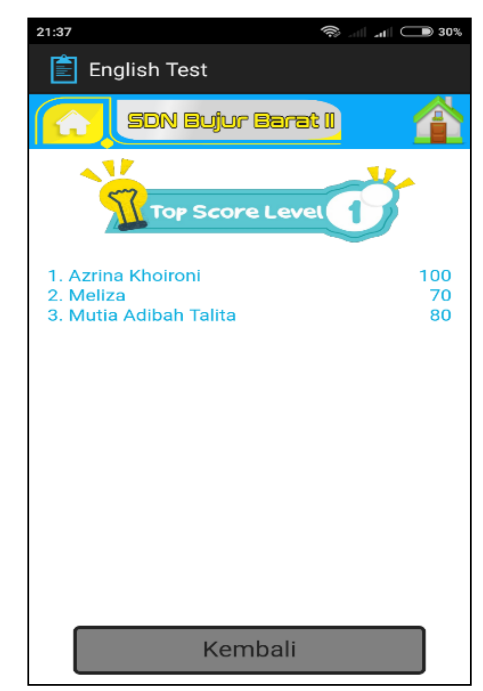

Gambar 20 Contoh Tampilan Menu Top Score

Setelah menerapkan game edukasi ini, siswa menjadi lebih tertarik pada mata pelajaran bahasa inggris. Tampilan media pembelajaran yang dibuat lebih atraktif dapat menggugah siswa untuk terus mempelajari dan mengasah kemampuannya. Hal ini tentu sangat berpengaruh pada hasil belajar siswa yang diharapkan dapat lebih baik dari sebelumnya.

\section{Kesimpulan}

Berdasarkan hasil penelitian yang dilakukan maka dapat ditarik kesimpulan bahwa penelitian ini dapat menghasilkan game edukasi yang dapat menyajikan materi dan pertanyaan sebagai evaluasi pembelajaran siswa, sehingga dapat menjadi sarana alternatif untuk menunjang pembelajaran. Hasil penelitian dan uji coba menunjukan dengan pembuatan game edukasi bahasa Inggris yang interaktif, pengguna merasa belajar bahasa Inggris menjadi lebih menyenangkan.

\section{Ucapan Terimakasih}

Penulis ucapkan terima kasih kepada semua pihak yang telah membantu penulis untuk menyelesaikan penelitian ini, khususnya kepada pihak sekolah SDN Bujur Barat II yang bersedia dijadikan sebagai objek penelitian dalam pembuatan game edukasi ini.

\section{Daftar Rujukan}

[1] Ubaidi and N. P. Dewi. 2018. Menggunakan Fingerprint Dan Sms Gateway Di Pondok Pesantren Al-Amien Prenduan Madura. J. SPIRIT, vol. 10, no. 2, pp. 66-72.

[2] S. Y. Tao, Y. H. Huang, and M. J. Tsai. 2017.Applying the Flipped Classroom with Game-Based Learning in Elementary School Students' English Learning,. Proc. - 5th Int. Conf. Educ. Innov. through Technol. EITT 2016, pp. 59-63.

[3] W. C. Hsu and H. C. K. Lin. 2017.Impact of Applying WebGL Technology to Develop a Web Digital Game-Based Learning System for Computer Programming Course in Flipped Classroom. Proc. - 5th Int. Conf. Educ. Innov. through Technol. EITT 2016, no. 2004, pp. 64-69.

[4] A. V. Vitianingsih. 2016.Game Edukasi Berbasis Android Sebagai Media Pembelajaran Untuk Anak Usia Dini. Inf. (jurnal Ilm. Bid. Teknol. Inf. dan komunikasi), vol. 1, no. 1, pp. $46-58$.

[5] D. Suryana. 2017. Perancangan Aplikasi Game Edukasi Untuk Meningkatkan Kemampuan Daya Berpikir Anak Usia Dini Berbasis Android.

[6] D. wahyu Putra, A. P. Nugroho, and E. W. Puspitarini. 2014. Rancang Bangun Aplikasi Mobile Untuk Notifikasi Jadwal. J. Teknol. Inf. dan Komunikasi, vol. 5, no. 1, pp. 47-55.

[7] W. A. Septiko, M. A. Akbar, and T. Afirianto. 2018 Pengembangan Game Edukasi Platformer Kisah Gajah Mada Menyatukan Nusantara Menggunakan Metode Iterative With Rapid Prototyping. J. Pengemb. Teknol. Inf. dan Ilmu Komput. Univ. Brawijaya, vol. 2, no. 12, pp. 5983-5989.

[8] R. Meimaharani and T. Listyorini. 2018.Purwarupa Game Edukasi Pengenalan Warna Berbasis Android. Syst. Inf. Syst. Informatics J., vol. 1, no. 2, pp. 27-31.

[9] S. Priyanto, P. Pribadi, and A. Hamdi. 2014. Game Edukasi 'Matching Three' Untuk Anak Usia Dini. J. Telemat., vol. 7, no. 2, pp. 32-51.

[10] M. Firdaus and H. W. Nugroho. 2016. Rancang Bangun Game Edukasi Asah Otak Anak Berbasis Android Menggunakan Aplikasi Construct 2. Progr. Stud. Tek. Inform., pp. 1-10. 